\title{
PENERAPAN PENILAIAN DIRI UNTUK MENINGKATKAN EFIKASI DIRI SISWA DALAM PEMBELAJARAN MATEMATIKA
}

\author{
Jihan Auliya', Gusti Ayu Mahayukti' ${ }^{2}$ I Nyoman Gita ${ }^{3}$ \\ 1,2,3 Program Studi S1 Pendidikan Matematika, Jurusan Matematika, \\ Universitas Pendidikan Ganesha \\ E-mail : jihan.auliya1010@gmail.com; gustiayumahayukti@gmail.com; \\ inyomangita@gmail.com
}

\begin{abstract}
ABSTRAK
Penelitian ini bertujuan untuk mengetahui: (1) peningkatan efikasi diri siswa dalam pembelajaran matematika, dan (2) tanggapan siswa terhadap penerapan strategi penilaian diri. Jenis penelitian ini adalah penelitian tindakan kelas yang dilaksanakan dalam tiga siklus, pada semester genap Tahun Ajaran 2017/2018 dengan subjek penelitian ini adalah siswa kelas XI TKJ 1 SMK Negeri 3 Singaraja sebanyak 27 orang siswa. Data efikasi diri siswa dikumpulkan menggunakan kuesioner efikasi diri, dan tanggapan siswa dikumpulkan menggunakan angket tanggapan siswa. Data yang telah terkumpul selanjutnya dianalisis secara deskriptif. Hasil penelitian menunjukkan bahwa rata-rata skor efikasi diri siswa mengalami peningkatan sebesar 8,53 dari 77,07 pada siklus I menjadi 85,6 pada siklus II, dan sebesar 2,9 dari 85,6 pada siklus II menjadi 88,5 pada siklus III, serta rata-rata skor tanggapan siswa telah berada dalam kategori sangat positif. Peningkatan efikasi diri siswa terjadi karena guru lebih menekankan pada: (1) pemberian kesempatan siswa untuk melakukan penilaian diri yang sangat efektif, (2) pemberian umpan balik yang cepat dari guru kepada siswa, (3) pemberian bimbingan dan motivasi kepada siswa agar semakin percaya diri dalam pembelajaran matematika.
\end{abstract}

Kata kunci: penilaian diri, efikasi diri siswa, tanggapan siswa.

\section{ABSTRACT}

This research was aims to determine: (1) the improvement of students' self efficacy in mathematics learning, and (2) students response toward self assessment learning strategy implementation. This research was a classroom action research which conducted in three cycles on even semester academic years 2017/2018 which the subject of this research was the students in class XI TKJ 1 SMK Negeri 3 Singaraja consisted of 27 students. The students' self efficacy's data was obtained by self efficacy questionnaire, and the students' response was obtained by inquiry questions. All of data had been collected and then analyzed descriptively. The results showed that students' self efficacy an increased 8,53 from 77,07 in first cycle to 85,6 in second cycle, and an increased 2,9 from 85,6 in second cycle to 88,5 in third cycle. The average students' response score have been in very positive category. The self efficacy's improvement can also occurs caused by teacher is more emphasis on : (1) provision an opportunity for students to doing self assessment which is that very effective, (2) The fast feedback provision from teacher to students (3) provision of guidance and motivation to students' to be more confident in learning mathemathics.

Key words: Self assessment, students' self efficacy, students' response. 


\section{PENDAHULUAN}

Pendidikan merupakan salah satu aspek yang memegang peranan penting dalam perkembangan dan kemajuan taraf hidup suatu bangsa. Hal tersebut sejalan dengan perkembangan tuntutan dunia kerja yang tidak hanya membutuhkan Sumber Daya Manusia (SDM) yang berorientasi untuk kebutuhan dunia industri, namun SDM yang dibutuhkan saat ini adalah SDM yang memiliki kompetensi unggul yang didampingi dengan kepercayaan diri yang tinggi dan berbagai karakter-karakter positif demi tercapainya tuntutan dunia kerja tersebut.

Kebutuhan pembentukan watak tersebut, perlu dipersiapkan untuk berpartisipasi terhadap terlaksananya program-progam pembangunan yang telah dicanangkan pemerintah guna memajukan perkembangan suatu bangsa sehingga terbentuk manusia yang berkualitas. Salah satu upaya untuk menciptakan manusia yang berkualitas adalah melalui pendidikan, maka dari itu kualitas pendidikan penting untuk selalu ditingkatkan.

Upaya-upaya peningkatan kualitas pendidikan tersebut slalu menjadi program pemerintah setiap periode pemerintahan, bahkan hampir tiap tahun ajaran selalu diperbaharui. Salah satunya dengan ditetapkannya UU. No. 20 Tahun 2003 tentang Sistem Pendidikan Nasional dan dijelaskan lebih lanjut dalam Peraturan Pemerintah No. 19 Tahun 2005 tentang Standar Nasional Pendidikan yang hingga saat ini masih menjadi acuan penting dalam perjalanan pendidikan di Indonesia.

Perubahan kurikulum dari kurikulum KTSP menjadi kurikulum 2013 juga dimaksudkan agar peserta didik mampu mengkontruksi pengetahuannya sendiri dari berbagai aktifitas yang menuntut siswa untuk selalu aktif saat proses pembelajaran dalam hal ini proses pembelajaran tidak lagi berpusat pada guru (Teacher centered) melainkan berpusat pada siswa (Student centered). Tugas guru dalam hal ini adalah sebagai pendorong dan pembimbing saat berlangsungnya pembelajaran dikelas. Apabila penerapan kurikulum 2013 dapat berjalan secara optimal maka besar kemungkinan peningkatan kualitas pendidikan dapat meningkat sehingga mutu pendidikan di Indonesia mengalami peningkatan.

Berdasarkan hasil wawancara peneliti kepada siswa, beberapa siswa menyatakan bahwa matematika pada Sekolah Menengah Kejuruan merupakan salah satu mata pelajaran normatif yang amat diunggulkan dibanding mata pelajaran lain disamping juga terdapat mata pelajaran produktif yang ditekuni siswa. Siswa SMK khususnya pada masing-masing tingkatan, mulai kelas X, XI, dan XII kurang lebih memiliki banyak ketertarikan pada mata pelajaran Matematika. Namun masih ada siswa yang memiliki tingkat efikasi diri (kepercayaan diri) rendah dan masih beranggapan bahwa matematika merupakan mata pelajaran yang sulit bahkan menakutkan. Bertolak dari anggapan tersebut dapat mempengaruhi mental siswa yang menimbulkan sifat negatif pada siswa, antara lain siswa enggan untuk mengikuti pelajaran matematika, takut dan benci jika ada jadwal pelajaran matematika, bahkan terkadang kebencian siswa tersebut tidak hanya pada mata pelajarannya saja tetapi juga pada guru yang mengajar.

Permasalahan tersebut terjadi di SMK Negeri 3 Singaraja kelas XI TKJ 1 tahun ajaran 2017/2018. Hasil observasi awal yang dilakukan peneliti di kelas XI TKJ 1 SMK Negeri 3 Singaraja pada bulan Oktober 2017, tingkat efikasi diri siswa masih tergolong rendah. Beberapa hasil wawancara secara langsung kepada guru pengajar dan siswa memberikan keterangan sebagai berikut. Untuk pelajaran Matematika, secara umum dari semua kelas yang guru pengajar ampu berbeda keadaan kelasnya. Terdapat kelas yang seimbang kondisi kelasnya (seimbang untuk siswa yang kemampuan lebih mumpuni dan yang kurang mumpuni) namun terdapat juga kelas yang tidak seimbang. Khusus di kelas XI TKJ 1 siswanya lumayan mumpuni untuk tingkat kemampuan akademiknya karena mungkin sudah melalui proses seleksi dengan tes pemetaan, sehingga di kelas XI TKJ 1 ini sudah dapat digolongkan kelas yang bagus dan tingkat 
atas. Namun hal yang kontradiktif terjadi di kelas ini, yakni siswa dengan kemampuan akademik yang bagus memiliki kepercayaan diri yang kurang sehingga dalam meraih hasil tes (nilai kognitif/pengetahuannya) sudah baik, namun jika diminta menyampaikan pengetahuan yang mereka miliki masih banyak yang tidak mampu. Jadi, terdapat kesulitan bagi guru untuk menilai proses pembelajaran baik dari ranah afektif (sikap) dan psikomotor (keterampilan). Terdapat juga fakta bahwa beberapa siswa yang membuat koloni sendiri-sendiri di dalam kelas (berkelompok). Hal seperti ini yang kiranya menjadi permasalahan signifikan di kelas dan dipandang perlu untuk dicari jalan keluarnya karena kebutuhan pembelajaran di masa sekarang yang semakin. Penggunaan model pembelajaran oleh guru juga kurang bervariasi. Saat pembelajaran berlangsung hanya metode ceramah yang paling signifikan digunakan dalam proses pembelajaran diawali dengan guru menjelaskan materi, kemudian memberikan contoh soal dan latihan soal kepada siswa, dan meminta beberapa siswa untuk mengerjakannya di depan kelas. Di akhir pembelajaran guru sering memberikan kuis sebagai evaluasi jalannya pembelajaran (post test). Guru menginstruksikan siswa melaksanakan penilaian diri, dengan cara memeriksa hasil kuis pada pertemuan sebelumnya yang telah dikerjakan siswa. Dengan cara ini guru juga telah melaksanakan tuntutan dalam Kurikulum 2013 yang diterapkan di sekolah ini, namun intensitasnya masih perlu ditingkatkan.

Selain permasalahan yang telah disebutkan sebelumnya yaitu sebagai berikut: 1) Siswa kurang percaya diri/enggan menyampaikan ide-ide maupun gagasannya terkait materi saat pembelajaran di kelas berlangsung. Hal ini terlihat jelas salah satunya saat guru telah selesai menjelaskan siswa tidak ada yang mengajukan pertanyaan kepada guru, 2) Siswa tampak ragu-ragu menjawab pertanyaan guru, serta kurang tegas mengemukakan pendapat. Hal ini terlihat jelas saat siswa menjawab pertanyaan guru dengan gugup, karena siswa belum yakin bahwa jawaban yang ingin disampaikan itu benar.

Wawancara dengan beberapa siswa diperoleh hasil sebagai berikut. 1) Siswa merasa banyak keraguan dengan jawaban yang dibuat, sehingga siswa enggan mengemukakannya pada guru, 2) Guru jarang memberikan kesempatan pada siswa untuk dapat mengevaluasi terkait pelaksanaan pembelajaran, misal untuk dapat menilai dan memberikan komentar terkait tugas atau pekerjaan rumah siswa tersebut. Namun sesekali guru hanya sempat melaksanakan peer assessment (penilaian teman sejawat) tanpa memberikan jawaban akhir yang benar. Siswa takut mengemukakan ide-ide/gagasannya karena kebanyakan siswa takut salah pada saat menjawab pertanyaan yang diberikan guru. Akibatnya dalam pembelajaran di kelas siswa cenderung pasif.

Setelah melakukan wawancara kepada guru dan siswa, peneliti melakukan observasi secara langsung di dalam kelas untuk mengetahui sejauh mana tingkat efikasi diri siswa.

Sehubungan dengan identifikasi permasalahan di atas, dapat disimpulkan bahwa siswa di kelas XI TKJ 1 SMK Negeri 3 Singaraja memiliki permasalahan yakni rendahnya kemampuan efikasi diri. Hal ini dapat memberikan dampak pada kegiatan pembelajaran yang dilaksanak siswa di dalam kelas dan akan berdampak pada rendahnya kemampuan siswa dalam mengkomunikasikan dengan benar pada permasalahan yang diberikan, sehingga siswa akan susah untuk mempercayai dirinya sendiri dan akhirnya akan berdampa pada tidak terpenuhinya kriteria ketuntasan bagi siswa tersebut. Oleh karena itu, tingkat efikasi diri siswa tersebut perlu mendapat perhatian lebih dan diselesaikan dengan baik.

Berdasarkan beberapa uraian masalah yang telah dipaparkan sebelumnya, penelitian ini bertujuan untuk mengetahui peningkatan Efikasi Diri dan Prestasi Belajar Siswa kelas XI TKJ 1 SMK Negeri 3 Singaraja melalui Penerapan Penilain Diri dalam Pembelajaran Matematika. 


\section{METODE PENELITIAN}

Penelitian ini merupakan jenis penelitian tindakan kelas kolaboratif (collaborative classroom action research) yang secara umum bertujuan untuk meningkatkan dan memperbaiki kualitas, proses, dan hasil pembelajaran matematika XI TKJ 1 SMK Negeri 3 Singaraja yang bermuara pada peningkatan efikasi diri siswa.

Subjek penelitian adalah siswa kelas XI TKJ 1 SMK Negeri 3 Singaraja pada semester genap tahun pelajaran 2017/2018 sebanyak 27 orang yang terdiri dari 5 orang perempuan dan 22 orang laki-laki. Alasan pengambilan subjek penelitian ini karena di kelas tersebut terungkap permasalahanpermasalahan yang terjadi dalam proses pembelajaran terutama tingkat efikasi diri siswa kelas XI TKJ 1 SMK Negeri 3 Singaraja masih perlu ditingkatkan, seperti yang telah dipaparkan pada pendahuluan.

Penelitian ini dilaksanakan dalam tiga siklus dimana setiap siklus terdiri dari empat tahapan yaitu perencanaan tindakan, pelaksanaan tindakan, observasi/evaluasi, dan refleksi. Pada setiap siklus dilaksanakan sebanyak 4 kali pertemuan dengan rincian untuk pelaksanaan pembelajaran dan 1 kali pertemuan untuk pemberian kuesioner efikasi diri siswa dan serta pada pertemuan terkhir siswa diberikan angket tanggapan siswa terkait strategi penilaian diri yang dilaksanakan.

Data mengenai Efikasi Diri siswa dikumpulkan dengan pemberian kuesioner kepada siswa dan data tanggapan siswa terhadap penerapan strategi penilaian diri dikumpulkan menggunakan angket yang terdiri dari 15 item yang diberikan pada akhir siklus III. Angket tanggapan siswa diukur dengan menggunakan Skala Likert dengan menggunakan dimensi dan indikator efikasi diri siswa dijelaskan pada Tabel 1.

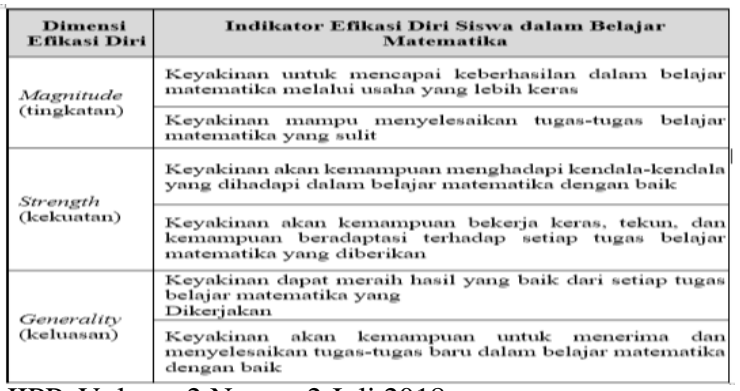

JIPP, Volume 2 Nomor 2 Juli 2018
Tabel 1. Dimensi dan indikator efikasi diri siswa

Data efikasi diri siswa dianalisis secara deskriptif menggunakan rubrik penskoran untuk masing-masing pernyataan yang terdapat pada kuesioner yang diringkas pada Tabel 2 berikut.

Tabel 2. Rubrik Penskoran untuk Indikator Efikasi Diri

Selanjutnya data yang diperoleh

\begin{tabular}{|c|c|c|c|}
\hline \multirow{2}{*}{ No } & \multirow{2}{*}{ Pilihan } & \multicolumn{2}{|c|}{ Skala Pemberian Skor } \\
\cline { 3 - 4 } & & Pernyataan Positif & Pernyataan Negatif \\
\hline 1 & SS (Sangat Setuju) & 5 & 1 \\
\hline 2 & S (Setuju) & 4 & 2 \\
\hline 3 & KS (Kurang Setuju) & 3 & 3 \\
\hline 4 & TS (Tidak Setuju) & 2 & 4 \\
\hline 5 & STS (Sangat Tidak Setuju) & 1 & 5 \\
\hline
\end{tabular}

dianaliis berdasarkan nilai rata-rata $(\bar{X})$ seperti yang tercantum pada Tabel 3 berikut.

Tabel 3. Kriteria Penggolongan Efikasi Diri Siswa.

\begin{tabular}{|c|c|}
\hline Rentang Skor & Kategori \\
\hline $\bar{X} \geq 80$ & Sangat Tinggi \\
\hline $60 \leq \bar{X}<80$ & Tinggi \\
\hline $40 \leq \bar{X}<60$ & Cukup \\
\hline $20 \leq \bar{X}<40$ & Rendah \\
\hline $\bar{X}<20$ & Sangat Rendah \\
\hline
\end{tabular}

Sedangkan data tanggapan siswa terhadap penerapan strategi penilaian diri dianalisis secara deskriptif, yakni dengan menghitung rata-rata skor tanggapan siswa dengan kriteria penggolongan yang disajikan pada Tabel 4.

Tabel 4. Kriteria Penggolongan Tanggapan Siswa

Dari analisis data tersebut, penelitian

\begin{tabular}{|l|c|}
\hline \multicolumn{1}{|c|}{ Rentang Skor } & Kategori \\
\hline $\bar{T} \geq M I+1,8 S D I$ & Sangat Positif \\
\hline$M I+0,6 S D I \leq \bar{T}<M I+1,8 S D I$ & Positif \\
\hline$M I-0,6 S D I \leq \bar{T}<M I+0,6 S D I$ & Ragu-ragu \\
\hline$M I-1,8 S D I \leq \bar{T}<M I-0,6 S D I$ & Negatif \\
\hline $\bar{T}<M I-1,8 S D I$ & Sangat Negatif \\
\hline
\end{tabular}

ini menetapkan kriteria keberhasilan yaitu rata-rata skor kuesioner efikasi diri siswa berada dalam kategori tinggi, rata-rata nilai prestasi belajar siswa berada pada kategori tuntas (nilai prestasi belajar $\geq 62$ ), mengalami peningkatan dari siklus I hingga 
siklus III, serta presentase daya serap klasikal dan ketuntasan belajar klasikal masing-masing mencapai $72 \%$ dan $70 \%$ dari total keseluruhan siswa. Sedangkan, untuk, rata-rata skor tanggapan siswa tehadap penerapan strategi penilaian diri minimal dalam kategori positif.

\section{HASIL DAN PEMBAHASAN \\ Hasil Penelitian}

Data Efikasi Diri Siswa

Berikut akan disajikan data efikasi diri siswa selama penelitian berlangsung, dari awal pelaksanaan siklus I sampai dengan di akhir pelaksanaan siklus III.

\begin{tabular}{|c|c|c|c|c|}
\hline Tahapan & Jumlah Skor & Rata-rata Skor & Peningkatan & Kategori Rata-rata \\
\hline Siklus I & 2081 & 77,07 & - & Tinggi \\
\hline Siklus II & 2313 & 85,6 & 8,53 & Sangat Tinggi \\
\hline Siklus III & 2391 & 88,5 & 2,9 & Sangat Tinggi \\
\hline
\end{tabular}

Tabel 5. Ringkasan Data Efikasi Diri Siswa

Dari tabel di atas, terlihat bahwa efikasi diri siswa kelas XI TKJ 1 SMK Negeri 3 Singaraja mengalami peningkatan setiap siklusnya, bahkan di siklus I sudah mencapai indikator keberhasilan yang ditetapkan, yakni dengan rata-rata skor 77,07 berada dalam kategori "Tinggi." Seperti yang dapat dilihat juga di siklus II dan siklus III ratarata skor efikasi diri siswa yakni 85,6 dan 88,5 juga merupakan hasil peningkatan yang diharapkan, bahkan sudah mampu mencapai kategori "Sangat Tinggi." Peningkatan ratarata skor efikasi diri siswa disajikan pada gambar berikut.

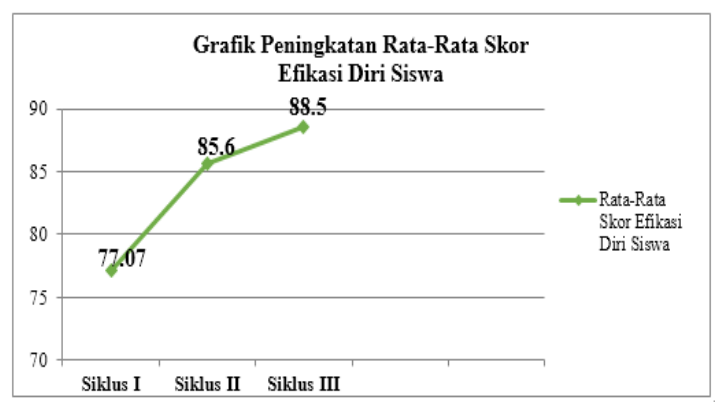

Gambar 1. Grafik Peningkatan Rata-rata Skor Efikasi Diri Siswa pada Siklus I, II, dan III.

b. Data Tanggapan Siswa

Pada akhir pertemuan siklus III, siswa juga diberikan angket untuk mengetahui tanggapan siswa terhadap penerapan strategi penilaian diri. Data mengenai tanggapan siswa terhadap penerapan penilaian diri ini, dikumpulkan pada akhir siklus III dengan menggunakan angket tanggapan siswa yang terdiri dari 15 butir pernyataan. Rata-rata skor tanggapan siswa terhadap penerapan strategi Penilaian Diri selama proses pembelajaran adalah sebagai berikut.

\begin{tabular}{|l|l|l|l|l|l|}
\hline & $\begin{array}{c}\text { Sangat } \\
\text { Kurang }\end{array}$ & Kurang & Cukup & Positif & $\begin{array}{c}\text { Sangat } \\
\text { Positif }\end{array}$ \\
\hline Banyak Siswa & 0 & 0 & 0 & 7 & 20 \\
\hline Presentase & $0 \%$ & $0 \%$ & $0 \%$ & $25,9 \%$ & $74,1 \%$ \\
\hline
\end{tabular}

Tabel 6. Persentase Tanggapan Siswa terhadap Penerapan Penilaian DiriSebaran data mengenai tanggapan siswa terhadap penerapan Strategi Penilaian Diri disajikan pada gambar berikut.

Berdasarkan rata-rata skor tanggapan siswa terhadap penerapan strategi Penilaian Diri selama proses pembelajaran, dapat disimpulkan bahwa pembelajaran melalui penerapan strategi Penilaian Diri mendapatkan tanggapan yang masuk dalam kategori "Sangat Positif" dari siswa sesuai dengan kriteria penggolongan tanggapan siswa, sehingga tanggapan siswa terhadap penerapan strategi penilaian diri selama proses pembelajaran telah memenuhi kriteria indikator keberhasilan yang ditetapkan.

\section{Pembahasan}

Berdasarkan hasil penelitian yang telah dilaksanakan dalam tiga siklus terlihat bahwa efikasi diri siswa kelas XI TKJ 1 SMK Negeri 3 Singaraja mengalami peningkatan dari siklus I sampai siklus III. Hal ini dapat dilihat dari adanya peningkatan hasil tindakan yang dilakukan untuk menyelesaikan permasalahan yang ditemui pada observasi dan setelah adanya pelaksanaan tindakan dari awal siklus I hingga berakhirnya siklus III telah mengalami perubahan dan peningkatan tersebut terus terjadi dari siklus ke siklus.

Melalui perbaikan-perbaikan yang dilakukan oleh guru dalam proses pembelajaran dari siklus I, siklus II dan siklus III membuat siswa mampu mengemukakan ide-ide yang mereka miliki seperti memberi bimbingan secara intensif, 
motivasi dan penguatan kepada siswa dengan begitu siswa lebih bersemangat dalam mempelajari materi yang telah diberikan, sehingga pada siklus III tidak terdapat lagi permasalahan yang berarti. Hal ini disebabkan karena proses pembelajaran pada siklus III ini sudah semakin baik dan sesuai dengan harapan yang direncanakan dibandingkan dengan siklus-siklus sebelumnya. Penerapan Penilaian Diri dalam pembelajaran matematika di kelas XI TKJ 1 SMK Negeri 3 Singaraja berjalan dengan lancar, sudah sesuai dengan teori karena kendala-kendala yang dihadapi mampu diselesaikan melalui refleksi setiap proses pembelajaran maupun setiap siklusnya sehingga efikasi diri dan prestasi belajar yang dimiliki siswa dalam pembelajaran yang dilakukan telah mengalami peningkatan dari siklus ke siklus.

Hal ini sejalan dengan beberapa penelitian yang telah dilaksanakan sebelumnya, antara lain sebagai berikut.

1) Santari (2015). Pemahaman konsep matematika siswa yang dibelajarkan dengan melakukan penilaian diri lebih baik daripada pemahaman konsep matematika siswa yang dibelajarkan dengan pembelajaran konvensional. Dengan kata lain, penilaian diri berpengaruh positif terhadap pemahaman konsep matematika siswa kelas VIII Non Unggulan SMP Negeri 2 Singaraja. 2) Rasminiati (2016). Penelitian yang dilakukan melalui beberapa pengujian hipotesis yang telah dilaksanakan, menunjukkan terdapat perbedaan terhadap prestasi belajar siswa yang mengikuti pembelajaran dengan melakukan evaluasi diri dan siswa yang mengikuti pembelajaran konvensional. Dengan kata lain, pembelajaran dengan evaluasi diri berpengaruh positif terhadap prestasi belajar matematika dan self efficacy siswa.

3) Farisi (2012). Penelitian yang dilakukan diperoleh bahwa Model ADS efektif, valid, reliabel dan meaningful sebagai instrument asesmen dan pengembangan karakter di berbagai konteks pendidikan. Respon guru terhadap model ADS beragam dan ambigu, terkait dengan persoalan hubungan simbiosis antara asesmen dan pembelajaran. Respon siswa terhadap model ADS juga "positif", dapat memperbaiki arah kerja; dipercaya meningkatkan peringkat, kualitas kerja, motivasi, dan belajar.

4) Sofiyah (2013). Penelitian yang dilakukan diperoleh bahwa hasil belajar sswa dengan menerapkan Penilaian Diri pada kegiatan praktikum lebih baik daripada hasil belajar siswa tanpa menerapkan Penilaian Diri pada kegiatan praktikum. Respon siswa setelah diterapkannya Penilaian Diri pada kegiatan praktikum juga sangat baik yaitu sebesar $84,3 \%$.

5) Siswaningsih, dkk (2012). Penelitian ini bertujuan memberikan feedback kepada siswa untuk dapat lebih meningkatkan pengetahuannya serta mendapatkan metode penilaian yang inovatif. Dari penelitian yang dilakukan diperoleh bahwa siswa dapat dikategorikan puas dengan feedback yang diberikan dengan menggunakan rubrik dari peer assessment dan Self Assessment.

Selain terjadi peningkatan efikasi diri siswa dan prestasi belajar siswa dalam pembelajaran matematika, dengan penerapan strategi penilaian diri ini juga mendapatkan respon sangat positif dari siswa. Dengan demikian, hasil penelitian ini telah memenuhi semua indikator keberhasilan yang telah ditetapkan. Jadi dapat disimpulkan penelitian telah berhasil.

\section{SIMPULAN DAN SARAN}

Berdasarkan hasil analisis data, temuan, dan pembahasan hasil penelitian, diperoleh simpulan sebagai berikut.

Pertama, Secara umum peningkatan efikasi diri siswa kelas XI TKJ 1 SMK Negeri 3 Singaraja dapat diringkas sebagai beriku: untuk efikasi diri siswa dari siklus I memperoleh rata-rata skor kuesioner yaitu 77,07. Skor tersebut sudah dalam kategori "Tinggi." Peningkatan yang signifikan terjadi pada siklus II, skor rata-rata kuesioner efikasi diri siswa meningkat menjadi 85,6 yang sudah termasuk dalam kategori "Sangat Tinggi". Kategori "Sangat Tinggi" juga kembali didapat di siklus III dengan peningkatan skor rata-rata kuesioner efikasi diri siswa menjadi 88,5 . 
Peningkatan ini terjadi karena berbagai tindakan yang telah dilakukan oleh guru yang berkolaborasi dengan peneliti selama proses penelitian, antara lain yaitu: 1) mengarahkan siswa melalui pertanyaan yang dapat membuat siswa mudah dalam mengkonstruksi jawaban atas permasalahan yang diberikan. 2) memberikan kesempatan lebih banyak kepada siswa untuk melakukan penilaian diri untuk dapat mempermudah memahami apa yang telah dilakukannya selama proses pembelajaran. 3) memberikan bimbingan dan motivasi kepada siswa agar aktif selama berdiskusi dan selalu berkonsentrasi dalam belajar. Selain itu guru juga menginfokan kepada siswa yang aktif akan diberi point tambahan, dengan begitu siswa siswa akan termotivasi untuk aktif dalam berdiskusi, 4) Menegur siswa yang tidak disiplin dalam kelompoknya dan meminta untuk lebih fokus melakukan diskusi kelompok.

Kedua, tanggapan siswa terhadap penerapan Penilaian Diri yang dikumpulkan melalui angket tanggapan siswa yaitu ratarata skor tanggapan siswa telah berada dalam kategori "Sangat Positif'. Berdasarkan persentase banyaknya siswa yang memberi tanggapan positif adalah $25,9 \%$ (7 orang) dan persentase yang memberi tanggapan sangat positif adalah $74,1 \%$ (20 orang). Secara keseluruhan tanggapan siswa terhadap penerapan penilaian diri tergolong sangat positif, yaitu dengan rata-rata skor tanggapan siswa sebesar 66,3 hal ini sesuai dengan indikator keberhasilan dalam penelitian ini.

Adapun saran yang dapat disampaikan berdasarkan hasil penelitian yang telah dilakukan adalah sebagai berikut.

Pertama, penerapan strategi Penilaian Diri dapat digunakan sebagai salah satu alternatif dalam upaya peningkatan efikasi diri dan prestasi belajar matematika yang dimiliki siswa. Untuk itu, kepada guru matematika pada umumnya, disarankan mencoba menerapkan strategi penilaian diri untuk meningkatkan efikasi diri siswa yang meliputi kepercayaan diri, membuat siswa semakin termotivasi dalam belajar, melatih kejujuran, kedisiplinan, dan masih banyak lagi pendidikan karakter yang bisa diterapkan. Sementara itu juga dengan penerapan penilaian diri dapat meningkatkan prestasi belajar matematika siswa. Hal ini sangat bermanfaat bagi meningkatnya kemampuan kognitif siswa.

Kedua, penerapan strategi penilaian diri tidak terlalu memerlukan kerja keras guru untuk senantiasa memfasilitasi siswa secara keseluruhan, karena guru memberikan keleluasaan kepada siswa untuk memberikan penilaian kpada hasil yang sudah dikerjakannya. Di samping itu, dalam kegiatan diskusi kelompok juga siswa mendapat pembimingan yang baik dari guru dan juga siswa dapat berdiskusi bersama teman kelompoknya. Di dalam kelas guru iharapkan dapat menjadi fasilitator dan mediator yang profesional, sehingga siswa dapat belajar dan memperoleh hasil yang optimal.

Ketiga, bagi pembaca yang ingin menerapkan strategi penilaian diri diharapkan mencermati kendala-kendala yang peneliti alami ketika pelaksanaan proses pembelajaran dalam penelitian, sehingga nantinya akan diperoleh hasil yang lebih baik daripada penelitian yang telah dilaksanakan oleh peneliti.

\section{DAFTAR RUJUKAN}

Allinson, C. W., \& Hayes, J. (1996). The cognitive style index; A measure of intuition-analysis for organizational research. Journal of Management studies, 3391), 119-135.

Arikunto, Suharsimi. 2009. Dasar-Dasar Evaluasi Pendidikan. Jakarta : Bumi Aksara.

Bailin, S., Case, R., Coombs, J. R., \& Daniels, L. B. (1999). Conceptualizing critical thinking. Journal of curriculum studies, 31(3), 285-302.

Bandura, A. 1997. Self Efficacy in Changing Society. USA : Stanford. 
Bawa, I Ketut. 2017. Pengaruh Asesmen Kinerja terhadap Disiplin dan Prestasi Belajar Matematika dengan Pengendalian Efikasi Diri Siswa SMP Negeri di Kota Singaraja. Disertasi (tidak diterbitkan). Program Pasca Sarjana. Singaraja. Universitas Pendidikan Ganesha.

Cameron, P. 2003. Penilaian Diri dalam Pembelajaran PAI. Istanbul : Istanbul Press.

Candiasa, I Made. 2010. Statistik Univariat dan Bivariat Disertai Aplikasi SPSS. Singaraja : Universitas Pendidikan Ganesha.

Farisi, Mohammad Imam. 2012. Pengembangan Asesmen Diri Siswa (Student Self Assessment) sebagai Model Penilaian dan Pengembangan Karakter. Surabaya. UNESA.

Gouba, L. (2008). The importance of mathematics in everyday life. African Istitute for mathematical Sciences, 6.

Hiebert, J., \& Lefevre, P. (1986). Conceptual and procedural knowledge in mathematics: An introductory analysis. Conceptua; and Procedural knowledge: The case of mathematics, 2, 1-27.

Hudojo, H. 2003. Pengembangan Kurikulum dan Pembelajaran Matematika. Surabaya: Universitas Negeri Malang.

Meier, D. 2000. Accelerated Learning Handbook. Bandung: Kafia.

Muslich, Mistar. 2011. Authentic Assessment: Penilaian Berbasis Kelas dan Kompetensi. Bandung: Refika Aditama.
NCTM. 2000. Mathematics Assessment: A Practical Handbook for Grades 612. United States of America: NCTM.

Ontario. 2007. "Student Self-Assessment". Tersedia pada www.edu.gov.on.ca/eng/literacynu meracy/.../studentselfassessment.pd f.

Rasminiati, Ni Made. 2016. Pengaruh Evaluasi Diri dalam Pembelajaran Matematika dan Self Efficacy Siswa Kelas VII SMP Negeri 1 Sukasada. Skripsi (tidak diterbitkan). Jurusan Pendidikan Matematika. Singaraja. Universitas Pendidikan Ganesha.

Santari, Nitha. 2015. Pengaruh Penilaian Diri terhadap Pemahaman Konsep Matematika Siswa Kelas VIII Non Uggulan SMP Negeri 2 Singaraja. Skripsi (tidak diterbitkan). Jurusan Pendidikan Matematika. Singaraja. Universitas Pendidikan Ganesha.

Siahaan, Meri Fuji. 2014. Kurikulum 2013 dan Penilaian Diri. Fakultas Ilmu Pendidikan. Tangerang-Lipo Karawaci. Universitas Pelita Harapan.

Siswaningsih, W., dkk. 2012. Penerapan Peer Assessment dan Self Assessment pada Tes Formatif Hidrokarbon untuk Feedback Siswa SMA Kelas X. Jurusan Pendidikan Kimia, FPMIPA. Jakarta. Universitas Pendidikan Indonesia.

Sudjana. 2005. Ranah Kognitif Tes Prestasi Belajar Siswa. Universitas Negeri Sebelas Maret. Solo: Mega Bintang Persada.

Suherman, E., dkk. 2003. Model Pemelajaran Matematika Kontemporer. Bandung: JICA UPI. 
Suherman, Erman 2003. Strategi Pembelajaran Matematika Kontemporer. Universitas Pendidikan Indonesia.

Trianto. 2010. Model Pembelajaran Terpadu Konsep, Metode, dan Implementasi dalam KTSP. Jakarta: Bumi Aksara.

Utami, Neng Resqi Sri. 2016. Hubungan antara Motivasi Belajar dan Efikasi Diri dengan Model Mental Siswa dalam Pembelajaran Larutan Elektolit dan Non-Elektrolit menggunakan Model Simayang. Bandar Lampung. Universitas Lampung.

Western and Northern Canadian Protocol (WNCP). 2006. Rethinking Classroom Assessment with Purpose in Mind. Manitoba: The Minister of Education.

Widoyoko, E. P.. 2014. Penilaian Hasil Pembelajaran di Sekolah. Yogyakarta: Pustaka Belajar. 